\title{
Importance of lactic acid bacteria in Asian fermented foods
}

\author{
Sook Jong Rhee*, Jang-Eun Lee, Cherl-Ho Lee \\ From 10th Symposium on Lactic Acid Bacterium \\ Egmond aan Zee, the Netherlands. 28 August - 1 September 2011
}

\begin{abstract}
Lactic acid bacteria play important roles in various fermented foods in Asia. Besides being the main component in kimchi and other fermented foods, they are used to preserve edible food materials through fermentation of other raw-materials such as rice wine/beer, rice cakes, and fish by producing organic acids to control putrefactive microorganisms and pathogens. These bacteria also provide a selective environment favoring fermentative microorganisms and produce desirable flavors in various fermented foods. This paper discusses the role of lactic acid bacteria in various non-dairy fermented food products in Asia and their nutritional and physiological functions in the Asian diet.
\end{abstract}

\section{Introduction}

Fermentation is one of the oldest forms of food preservation in the world. Fermented dairy products and their microbial and functional characteristics have been widely studied. Most East-Asian fermented foods are non-dairy products featuring various other food raw-materials such as cereals, soybeans, fruits, and vegetables, as well as fish and other marine products. The importance of lactic acid bacteria in fermented non-dairy foods and beverages was reviewed previously in the early 1990s in an overview of the role of lactic acid bacteria in kimchi, fermented fish products and vegetable yogurts [1]. The role of lactic acid bacteria in rice wine/beer fermentation has also been reported [2]. Steamed bread such as idli from India and puto from the Philippines, which are made with rice, are fermented by Leuconostoc. Korean sikhae and Philippine burong isda/dalag, which are made by mixing salted fish and cereals, are also fermented in early stages by Leuconostoc mesenteroides $[3,4]$. L. mesenteroides initiates relatively rapid growth in various plant materials (vegetables and cereals) over a wide range of temperatures and salt concentrations in comparison with other lactic acid bacteria. During growth, $L$. mesenteroides produces carbon dioxide and acids, leading to modification of the

\footnotetext{
* Correspondence: sjrhee@korea.ac.kr

Department of Food Technology, Korea University, Seoul, 136-701, Korea Full list of author information is available at the end of the article
}

environment as well as conditions that favor the growth of other lactic acid bacteria. Analogously, the various fermentation pathways initiated by $L$. mesenteroides include prominent roles for other lactic acid bacteria belonging to the genera Lactobacillus and Pediococcus at later stages.

The numerous fermented food products in Asia can be categorized into five groups: (1) fermented soybean products, (2) fermented fish products, (3) fermented vegetable products, (4) fermented bread and porridges, and (5) alcoholic beverages. Lactic acid bacteria are involved in all of these fermentations to a varying extent, having either positive or negative effects on the eventual product. In making soybean sauce and paste, souring is indicative of poor fermentation and should be avoided. It is caused by undesirable yeast contamination, which is related to the fact that soybeans are not favorable substrates for the growth of lactic acid bacteria. In the case of alcoholic fermentation, lactic acid bacteria generally deteriorate the quality of the products. However, in traditional cereal alcoholic fermentation, lactic acid bacteria during the initial stage of fermentation provide a favorable environment for later stage fermentations including alcohol production, thereby contributing to the characteristic taste and aroma of the beverage. In fermentation of vegetable-derived raw materials, lactic acid bacteria play a major role, and the optimum amount of acid production varies with the product type [5]. 
The advantages of acidic food fermentation are: (1) renders foods resistant to microbial spoilage and the development of food toxins, (2) makes foods less likely to transfer pathogenic microorganisms, (3) generally preserves foods between the time of harvest and consumption, (4) modifies the flavor of the original ingredients and often improves nutritional value [6].

Examples of lactic acid-fermented foods in Asia are given in Table 1. Products in the same category are similar in processing procedures and microorganisms but differ in name and usage per country $[1,5]$.

\section{Discussion}

\section{Rice-wine/beer}

Rice-wine is a generic name referring to alcoholic beverages made from cereals, mainly rice, in East-Asia. Traditional alcoholic beverages vary from crystal-clear products to turbid liquid or thick gruels and pastes. Clear products, which are generally called shaosingjiu in China, cheongju in Korea, and sake in Japan, contain around $15 \%$ alcohol and are designated as rice-wine, whereas turbid beverages, takju (or maggolli) in Korea and tapuy in the Philippines, contain less than $8 \%$ alcohol along with suspended insoluble solids and live yeasts, and are referred to as rice-beer [5].

The process of cereal alcohol fermentation involves a two-step fermentation; solid state fermentation wherein molds grow on raw or cooked cereals, which is called nuruk, followed by mashing the nuruk with additional cereals to produce alcohol by yeast. The dried and powdered nuruk is then mixed with water and stored in a cool place for several days to make the mother brew. During this period, microbial amylases and proteases are produced, which convert the starch present in the cereal raw-materials into sugars. The acid-forming bacteria in nuruk then produce organic acids, reducing the $\mathrm{pH}$ to below 4.5, which favors the growth of yeast at the later stage of alcohol fermentation. About two to three volumes of cooked grains and water are then added to the mother brew to prepare the first fermentation mash. Upon addition of new cooked grains and water to the mash, the production volume increases while the alcohol concentration and quality of the final product are enhanced. Multiple brews prepared by adding two to nine additions of newly cooked grains to the fermenting mash have been described in the old literatures [7].

The traditional method of rice-wine brewing was first industrialized by Japanese brewers in the early 20th century, who adopted a pure starter culture, rice koji, in combination with manufacturing technology developed in Europe. This production process was later transferred to Korea and China. Industrial production of rice wine involves steaming of polished rice, inoculation of mold, Aspergillus oryzae or Aspergillus kawachii, and incubation at $25^{\circ} \mathrm{C}-30^{\circ} \mathrm{C}$ for $2-3$ days. The mother brew is made by mixing of the starter culture, koji, with yeast seed mash and water, followed by incubation for another 3-4 days at $20^{\circ} \mathrm{C}$. The main brew is made by adding ca. 10 volumes of cooked rice and water to the mother brew, followed by fermentation for 2-3 weeks. The fermented mash is then filtered to obtain a clear liquid and aged in a cool place for 1-2 weeks, after which it is filtered again, bottled, and pasteurized [2]. Figure 1 compares the brewing processes of traditional rice-wine (samhaeju) and industrial rice-wine (sake).

Table 2 shows that the changes in microbiota during traditional Korean rice-wine (samhaeju) brewing differ from those of the industrial process (Japanese style cheongju or sake), which involves pure culture inoculation in a controlled fermentation process [2]. The contribution of acid-forming bacteria is large in traditional brewing, whereas it is relatively meager in the industrial process. In traditional brewing, lactic acid is the major organic acid produced, whereas industrial rice wine contains mostly succinic acid, which is most likely produced by molds and yeasts (Figure 2) [2]. Moreover, traditional rice wine contains significantly higher concentrations of ethylacetate (75 ppm) and lower concentrations of npropanol (70 ppm), isobutanol (125 ppm), and isoamylalcohol (210 ppm) relative to industrial products [2]. The differences in microbiota and concentrations of corresponding flavor compounds result in differential sensory qualities, wherein traditional rice-wine has a deep and bounty-like flavor and industrial ones are characterized by a more simple and light flavor.

\section{Acid-fermented bread and noodle}

Lactic acid fermentation of bread dough improves the keeping quality and flavor of the baked products. It also enhances the palatability of bread made from low grade flours and under-utilized cereals. Acid-fermented breads and pancakes are an important staple food for people in Africa and some parts of Europe and Asia [8].

Large quantities of acid-leavened bread and pancakes are consumed daily in India, Sri-Lanka, Pakistan, Nepal, Sikkim, Tibet, and neighboring countries. Idli, dosa, and dhokla are produced primarily in south India and Sri Lanka. Idli is a small, white, acid-leavened and steamed cake prepared by bacterial fermentation of a thick batter made from carefully washed and coarsely ground rice as well as dehulled and finely ground black gram dhal.Dosa batter is very similar to idli batter, except that the rice and black gram are both finely ground. Following fermentation, dosa is quickly fried as a thin, fairly crisp pancake and eaten directly. Dhokla is similar to idli except that dehulled Bengal gram dhal is used in place of black gram dhal. The fermented batter is poured into a greased pie tin and steamed in the open rather than in a covered idli 
Table 1 Examples of acid-fermented foods in Asia

\begin{tabular}{|c|c|c|c|c|}
\hline Product & Country & Major ingredients & Microorganisms & Appearance/ usage \\
\hline \multicolumn{5}{|l|}{ Rice-wine/beer } \\
\hline Takju & Korea & rice, wheat & $\begin{array}{l}\text { Lactic acid bacteria } \\
\text { Saccharomyces } \\
\text { cerevisiae }\end{array}$ & Turbid liquid \\
\hline Tapuy & Philippine & rice, glutinous rice & $\begin{array}{l}\text { Sacchromyces, } \\
\text { Mucor, Rhizopus, } \\
\text { Aspergilus } \\
\text { Leuconostoc } \\
\text { Lb. plantarum }\end{array}$ & Sour, sweet liquid, paste \\
\hline Brem bali & Indonesia & glutinous rice & Mucor indicus, Candida & $\begin{array}{l}\text { Dark brown liquid sour } \\
\text { alcoholic }\end{array}$ \\
\hline \multicolumn{5}{|c|}{ Acid-leavened bread/noodle } \\
\hline Idli & $\begin{array}{l}\text { India } \\
\text { Sri Lanka }\end{array}$ & $\begin{array}{l}\text { rice } \\
\text { black gum }\end{array}$ & $\begin{array}{l}\text { L. mesenteroides } \\
\text { S. faecalis }\end{array}$ & steamed cake \\
\hline Puto & Philippines & rice & $\begin{array}{l}\text { L. mesenteroides } \\
\text { Streptococcus faecalis }\end{array}$ & steamed cake \\
\hline Kichuddok & Korea & rice & yeast & steamed cake \\
\hline Mungbean & China & mungbean & L. mesenteroides & noodle \\
\hline $\begin{array}{l}\text { Starch } \\
\text { Noodle }\end{array}$ & $\begin{array}{l}\text { Thailand, Korea, } \\
\text { Japan }\end{array}$ & & $\begin{array}{l}\text { Lb. casei, } \\
\text { Lb. cellobiosus } \\
\text { Lb. fermenti }\end{array}$ & \\
\hline Khanomjeen & Thailand & rice & $\begin{array}{l}\text { Lactobacillus } s p . \\
\text { Streptococcus } s p .\end{array}$ & noodle \\
\hline \multicolumn{5}{|c|}{ Fermented vegetable } \\
\hline Kimchi & Korea & $\begin{array}{l}\text { Korean cabbage, radish, various } \\
\text { vegetables, salt }\end{array}$ & $\begin{array}{l}\text { L. mesenteroides } \\
\text { Lb. brevis, } \\
\text { Lb. plantarum }\end{array}$ & salad, side dish \\
\hline Dhamuoi & Vietnam & cabbage, vegetable & $\begin{array}{l}\text { L. mesenteroides } \\
\text { Lb. plantarum }\end{array}$ & salad, side dish \\
\hline Dakguadong & Thailand & mustard leaf & Lb. plantarum & salad, salt side dish \\
\hline $\begin{array}{l}\text { Burong } \\
\text { mustala }\end{array}$ & Philippines & mustard & $\begin{array}{l}\text { Lb. brevis } \\
\text { Pediococcus cerevisiae }\end{array}$ & salad, side dish \\
\hline \multicolumn{5}{|c|}{ Fermented fish and meat } \\
\hline Sikhae & Korea & $\begin{array}{l}\text { sea water fish } \\
\text { cooked millet, salt }\end{array}$ & $\begin{array}{l}\text { L. mesenteroides } \\
\text { Lb. plantarum }\end{array}$ & side dish \\
\hline Narezushi & Japan & $\begin{array}{l}\text { sea water fish } \\
\text { cooked millet, salt }\end{array}$ & $\begin{array}{l}\text { L. mesenteroides } \\
\text { Lb. plantarum }\end{array}$ & side dish \\
\hline Burong-isda & Philippines & $\begin{array}{l}\text { fresh water fish rice, } \\
\text { salt }\end{array}$ & $\begin{array}{l}\text { Lb. brevis, } \\
\text { Streptococcus sp. }\end{array}$ & side dish \\
\hline Pla-ra & Thailand & $\begin{array}{l}\text { fresh water fish salt, } \\
\text { roasted rice }\end{array}$ & Pediococcus sp. & side dish \\
\hline Balao-balao & Philippine & shrimp, rice, salt & $\begin{array}{l}\text { L. mesenteroides } \\
\text { P. cerevisiae }\end{array}$ & condiment \\
\hline Kungchao & Thailand & $\begin{array}{l}\text { shrimp, salt } \\
\text { sweetened rice }\end{array}$ & P. cerevisiae & side dish \\
\hline Nham & Thailand & pork, galic, salt, rice & $\begin{array}{l}\text { P. cerevisiae, } \\
\text { Lb. plantarum } \\
\text { Lb. brevis }\end{array}$ & pork meat in banana leaves \\
\hline Nem-chua & Vietnam & pork, salt, cooked rice & $\begin{array}{l}\text { Pediococcus } s p . \\
\text { Lactobacillus } s p .\end{array}$ & sausage \\
\hline
\end{tabular}

steamer. Figure 3 shows the flow chart of idli production [6].

L. mesenteroides and Streptococcus faecalis are developed concomitantly with soaking and then continue to multiply following grinding. Both genera eventually reach higher than $1 \times 10^{9}$ cells/gram of the finished batter
[9]. L. mesenteroides is considered to be essential for leavening of the batter, and it is also considered to be responsible for acid production in idli, dosa, and related products, together with $S$. faecalis.

These organisms appear to be present in the rawmaterial ingredients, and therefore it is generally not 


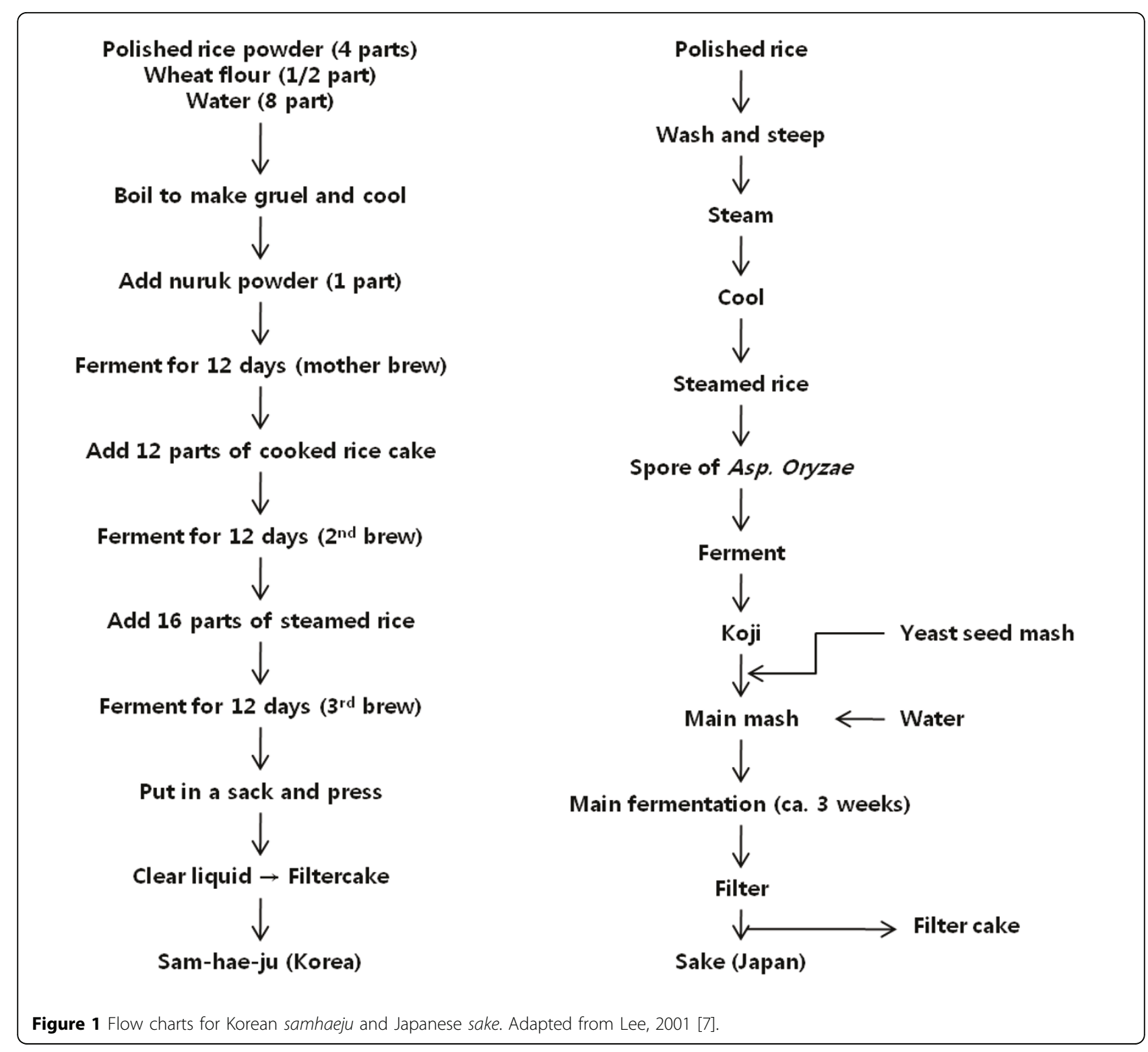

Table 2 Changes in concentrations of microorganisms during samhaeju and cheongju brewing

\begin{tabular}{|c|c|c|c|c|c|c|}
\hline \multirow[t]{2}{*}{ Microorganism (CFU/mL) } & \multirow[b]{2}{*}{ Batch } & \multicolumn{3}{|c|}{ samhaeju } & \multicolumn{2}{|c|}{ Japanese style cheongju } \\
\hline & & $1^{\text {st }}$ brew & $2^{\text {nd }}$ brew & $3^{\text {rd }}$ brew & Mother brew & Main brew \\
\hline \multirow[t]{3}{*}{ Mold } & A & $4.2 \times 10^{5}$ & $<10^{2}$ & ND & ND & ND \\
\hline & B & $9.8 \times 10^{4}$ & $<10^{2}$ & ND & ND & ND \\
\hline & C & $3.9 \times 10^{5}$ & $<10^{2}$ & ND & ND & ND \\
\hline \multirow[t]{3}{*}{ Acid forming bacteria } & $A$ & $3.1 \times 10^{5}$ & $8.9 \times 10^{7}$ & $8.6 \times 10^{4}$ & ND & $<10^{2}$ \\
\hline & B & $7.5 \times 10^{6}$ & $3.3 \times 10^{6}$ & $6.3 \times 10^{4}$ & ND & $<10^{2}$ \\
\hline & C & $3.3 \times 10^{5}$ & $8.5 \times 10^{7}$ & $7.5 \times 10^{4}$ & ND & $<10^{2}$ \\
\hline \multirow[t]{3}{*}{ Yeast } & A & $<10^{2}$ & $1.8 \times 10^{6}$ & $1.8 \times 10^{6}$ & $3.2 \times 10^{7}$ & $2 \times 10^{6}$ \\
\hline & B & $<10^{2}$ & $2.4 \times 10^{6}$ & $1.6 \times 10^{6}$ & $1.9 \times 10^{7}$ & $2.5 \times 10^{7}$ \\
\hline & C & $<10^{2}$ & $4.6 \times 10^{6}$ & $1.4 \times 10^{6}$ & $2.6 \times 10^{6}$ & $3.1 \times 10^{6}$ \\
\hline
\end{tabular}



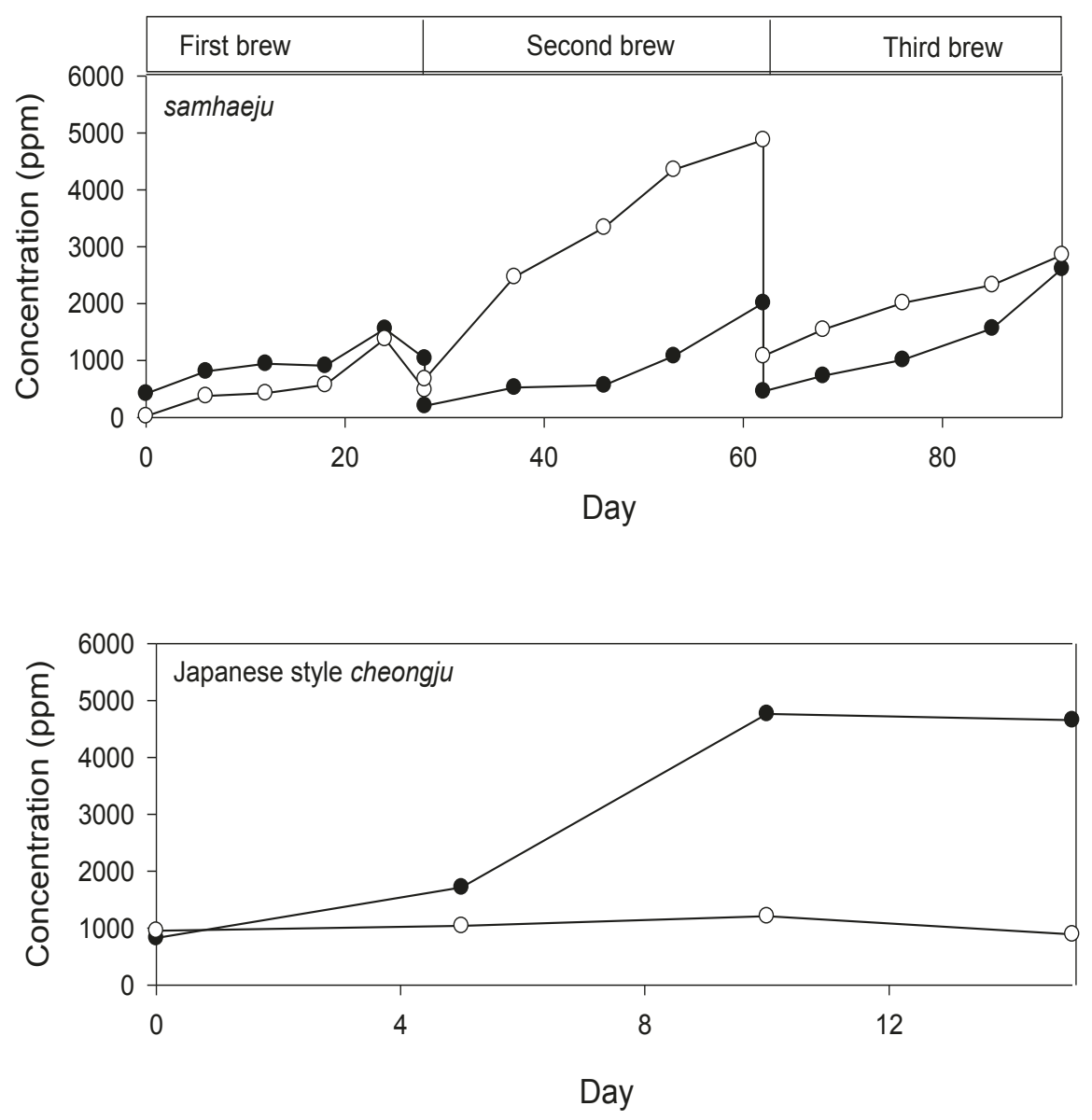

Figure $\mathbf{2}$ Changes in lactic acid( $(\circ)$ and succinic acid(•) contents during samhaeju and cheongju brewing. Adapted from Rhee et.al., 2003 [2].

required to add them as inoculum. Aerobic contaminants that are usually present in the raw-materials are eliminated partly by careful washing of the ingredients and partly by the acidic conditions generated by the fermentation. However, Batra and Millner [10] isolated Torulopsis candida and Trichosporon pulluans from idli batter and prepared authentic idli only by the joint action of both yeasts in the mixture. Both T. pullulans and T. candida provide characteristic acidity, whereas $T$. candida also produces gas during fermentation.

Leavened bread-type foods are not traditional staples in East Asia, although yeast-fermented breads are commonly used today. Chinese people have traditionally used steamed bread, mantou, which is prepared by steaming yeast-leavened wheat dough, often filled with sweets, meats, and vegetables. Other types of breads are prepared primarily by acid fermentation of rice flour dough, including Korean kichuddok and Philippine puto. These products are leavened, steamed rice cakes that are similar to Indian $i d l i$, except that they do not contain any legumes. Puto is special in the sense that it is prepared from year-old rice and its batter is neutralized at the mid-point of fermentation. Figure 4 shows the processing procedures of kichuddok and puto [7].

Kichuddok is prepared at the household level and consumed less frequently at special occasions in Korea, whereas puto is normally consumed as a breakfast and snack in the Philippines. Puto is a common food for the lower-income group, but special types with added cheese, eggs, etc., are consumed as delicacies by the higher-income group. In a number of Philippine towns, preparation of puto is an important cottage industry [7].

Thai rice-noodle, khanom-jeen, is also made from acid-fermented rice [11]. Soaked rice is drained and fermented for at least 3 days before grinding, and Lactobacillus species and Streptococcus species are involved in the acid fermentation. Acid-fermented porridges, such as ogi and $u j i$ in African countries, are not common in the Asia-Pacific region. 


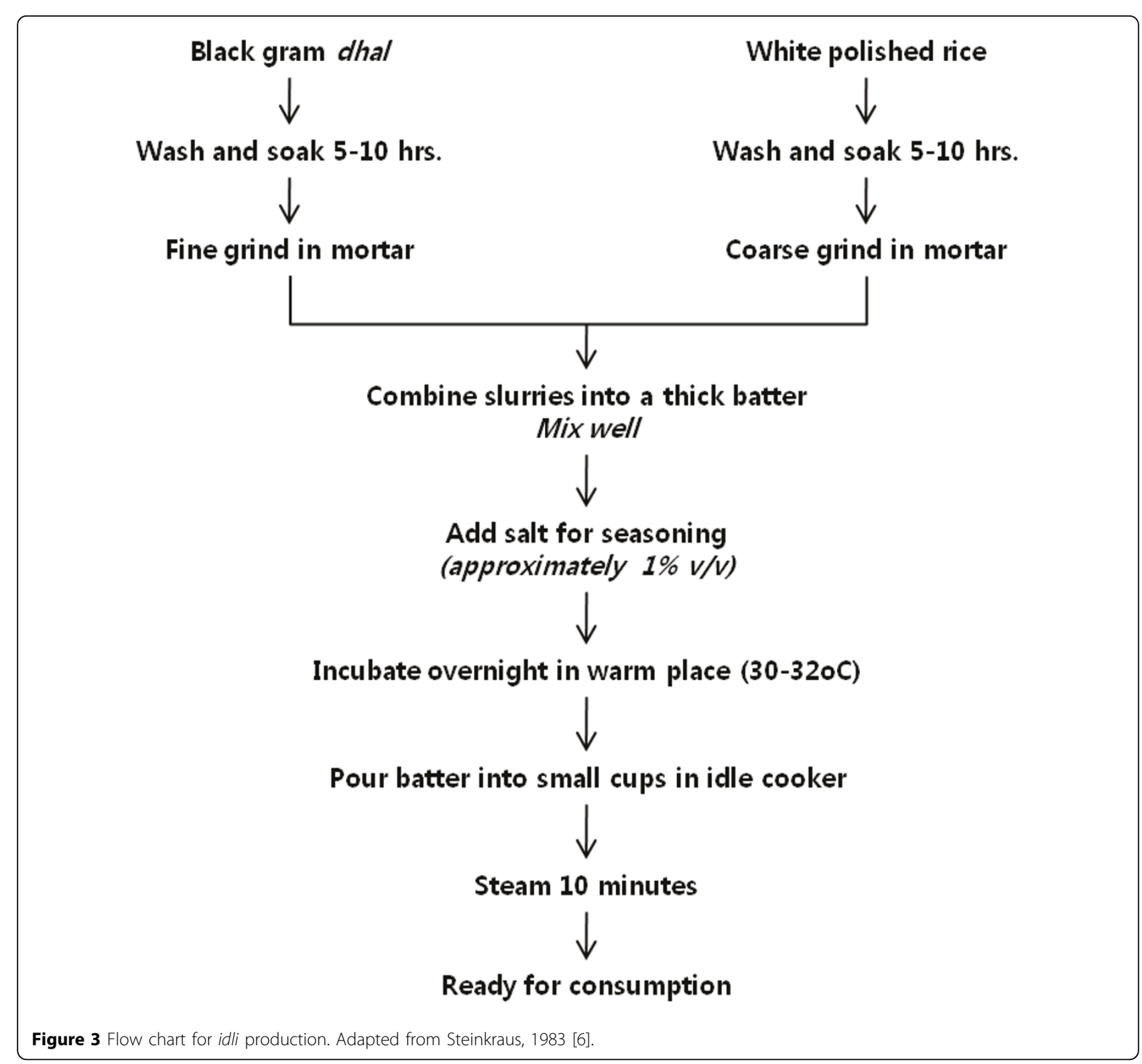

Most Asian countries produce mungbean starch, and mungbean starch noodles are dietary staples of the Chinese. The process for manufacturing mungbean starch involves acidic bacterial fermentation, in which the mungbeans are hydrated by soaking in water inoculated with 12 -hr steep water from a previous fermentation to ensure acidification. The principal microorganisms found in the steep water are $L$. mensenteroides, Lactobacillus casei, Lactobacillus cellobiosus, and Lactobacillusfermentum. Lactic acid fermentation, which reduces the $\mathrm{pH}$ from 6.0 to about 4.0 protects the starch granules from spoilage and putrefaction that would otherwise occur in non-inoculated ground bean slurries [7].

\section{Acid-fermented fish and meat}

The storage life of perishable fish and meats can been extended by acid-fermentation with added carbohydrates and salts. Both freshwater and seawater fish are preserved by this method. Rice, millet, flour, and even syrup or sugar are all used as carbohydrate sources. Millet is used as the main carbohydrate source in Northeastern countries, whereas in Southeastern countries, rice is commonly used as a carbohydrate source. The organic acids produced from the added carbohydrates in combination with salt control the extent of acid fermentation and keep the quality of the product [12]. Figure 5 illustrates the processing procedure of Korean sikhae and Philippine balao-balao [7]. 


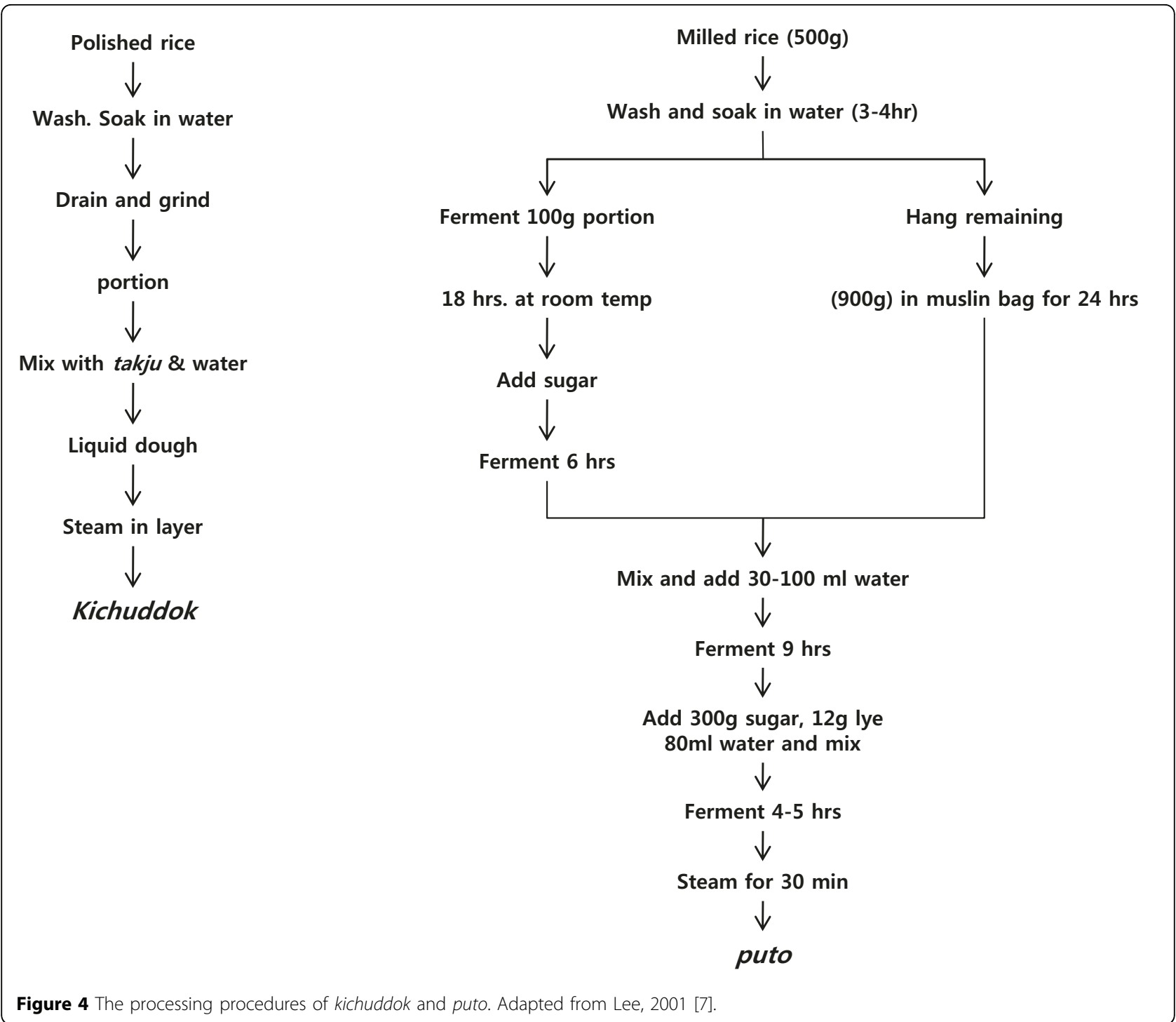

Figure 6 shows the microbial and biochemical changes of a typical lactic acid-fermented fish product, sikhae, incubated at $25^{\circ} \mathrm{C}$ [1]. The $\mathrm{pH}$ decreases rapidly during the first 3-5 days from 6.5 to below 5.0, whereas the texture softens within 3-4 days. The amino- $\mathrm{N}$ concentration increases steadily for 14 days, concomitant with the generation of optimum flavor. The number of lipolytic bacteria decreases rapidly during the initial stage of fermentation, whereas the number of proteolytic bacteria increases until 12 days of fermentation, followed by a rapid decrease thereafter. The typical acid-forming bacteria rapidly increase in number, becoming the predominant microbes within 1 week of fermentation and reaching their maximum density after 16 days. Typically, flavor deterioration in these products is associated with rapid growth of yeast [13]. Important bacteria for the lactic acid fermentation of sikhae have been identified as
L.mesenteroides and Lactobacillus plantarum [14]. The role of these acid-forming bacteria in the preservation of fish has been established, but an even more important contribution is their ability to produce acceptable flavor during fermentation of the product.

\section{Acid-fermented vegetables}

Acid-fermented vegetables are important sources of vitamins and minerals. L. mesenteroides has been found to be important in the initiation of fermentation of many vegetables, i.e. cabbages, beets, turnips, cauliflower, green beens, sliced green tomatoes, cucumber, olives, and sugar beet silages [1]. In vegetables, $L$. mesenteroides grows rapidly and produces carbon dioxide and acids that quickly lower the $\mathrm{pH}$, thereby inhibiting the development of undesirable microorganisms and the activity of their enzymes as well as preventing unfavorable softening of the vegetables. The 

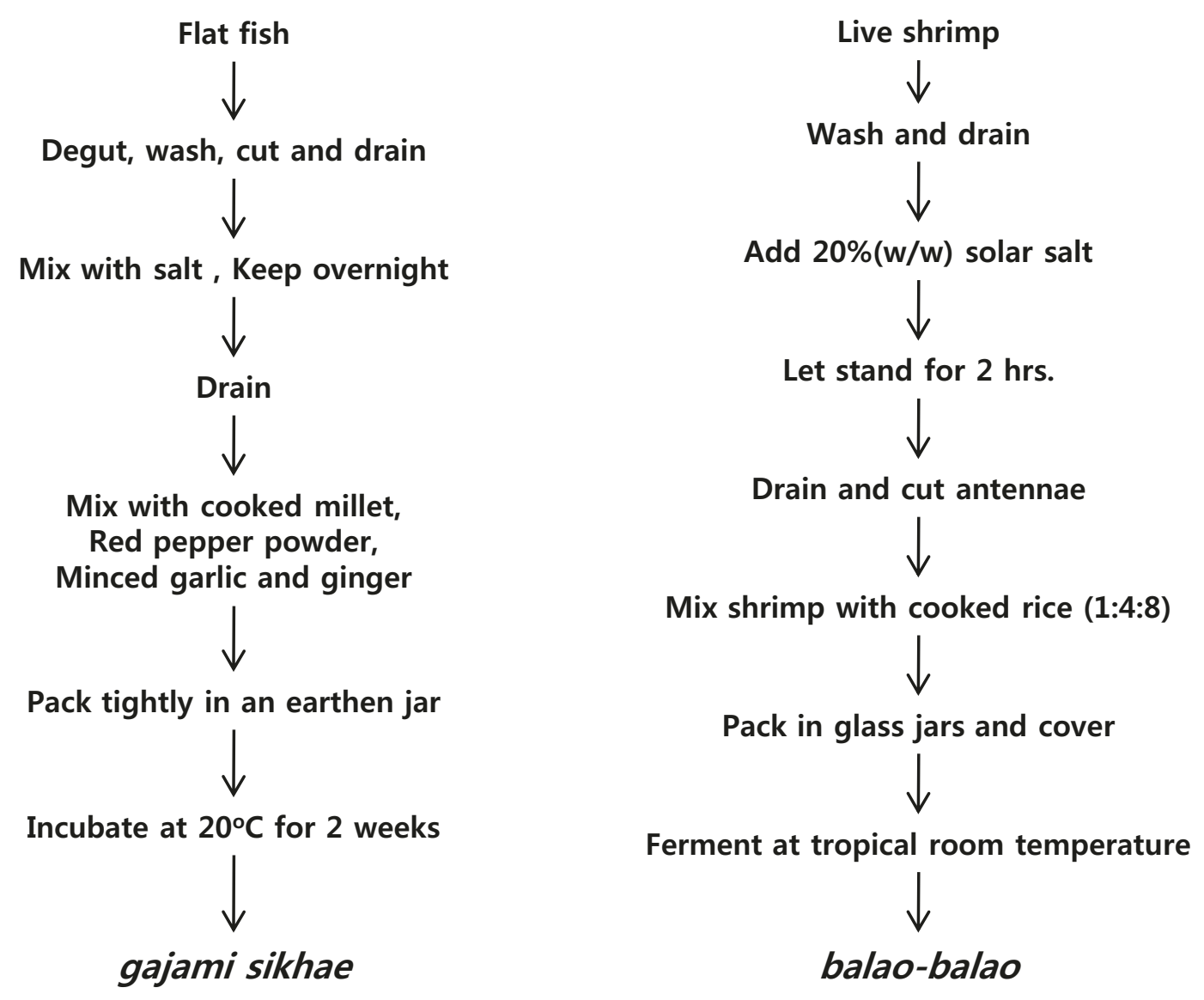

Figure 5 The processing procedure of Korean sikhae and Philippine balao-balao. Adapted from Lee, 2001 [7].

carbon dioxide produced replaces air and provides anaerobic conditions that favor stabilization of ascorbic acid and the natural colors of the vegetables. L. mesenteroides converts glucose to approximately $45 \%$ levorotatory D-lactic acid, $25 \%$ carbon dioxide, and $25 \%$ acetic acid and ethyl alcohol. Moreover, fructose is partially reduced to mannitol, which subsequently undergoes secondary fermentation (see below) to yield equimolar quantities of lactic acid and acetic acid. The combination of acids and alcohol are conducive to the formation of esters, which impart desirable flavors [1]. Overall, the initial growth of L. mesenteroides leads to modification of the environment that favors the growth of other lactic acid bacteria. Secondary fermentation in these processes, especially by homofermentative Lactobacillus species, leads to further reduction of the $\mathrm{pH}$ and ultimately growth of $L$. mesenteroides.

Kimchi fermentation is the Korean method of preserving the fresh and crispy texture of vegetables during the winter when fresh vegetables are not available. Almost all kinds of vegetables can be made into kimchi; cabbages, radish, cucumber, Welsh onion leaves, and mustard leaves are the popular main ingredients. The name of each particular kimchi is based on the main ingredients: cabbage kimchi (baechukimchi), radish kimchi, cucumber $k i m c h i$, etc. Minor ingredients such as garlic, red pepper, green onion, ginger, and salt are also added. Fermented fish products and other seasoning agents are optional. kimchi has a sour, sweet, and carbonated taste and is usually served cold [7]. It is a side dish that is commonly served with cooked rice and soup.

One recipe for cabbage kimchi may include $100 \mathrm{~g}$ of Korean cabbage, $2 \mathrm{~g}$ of garlic, $2 \mathrm{~g}$ of green onion, $2 \mathrm{~g}$ of red pepper powder, and $0.5 \mathrm{~g}$ of ginger, and the optimum salt content of the product is 3\% (Figure 7) [7]. For preparation, fresh cabbage is cut in half or shredded, soaked in brine of approximately $10 \%$ salt concentration overnight (or 15\% salt brine for 5-10 hours), and then washed and drained. The minor ingredients are chopped and mixed, with shredded radish stuffed between the salted cabbage leaves. The kimchi is then packed in an earthen jar, onggi or dok, buried in the ground, and pressed with a stone in order to submerge them in the juice. Winter kimchi is fermented for 1-2 months and consumed for 34 months until the end of the spring season. Figure 8 


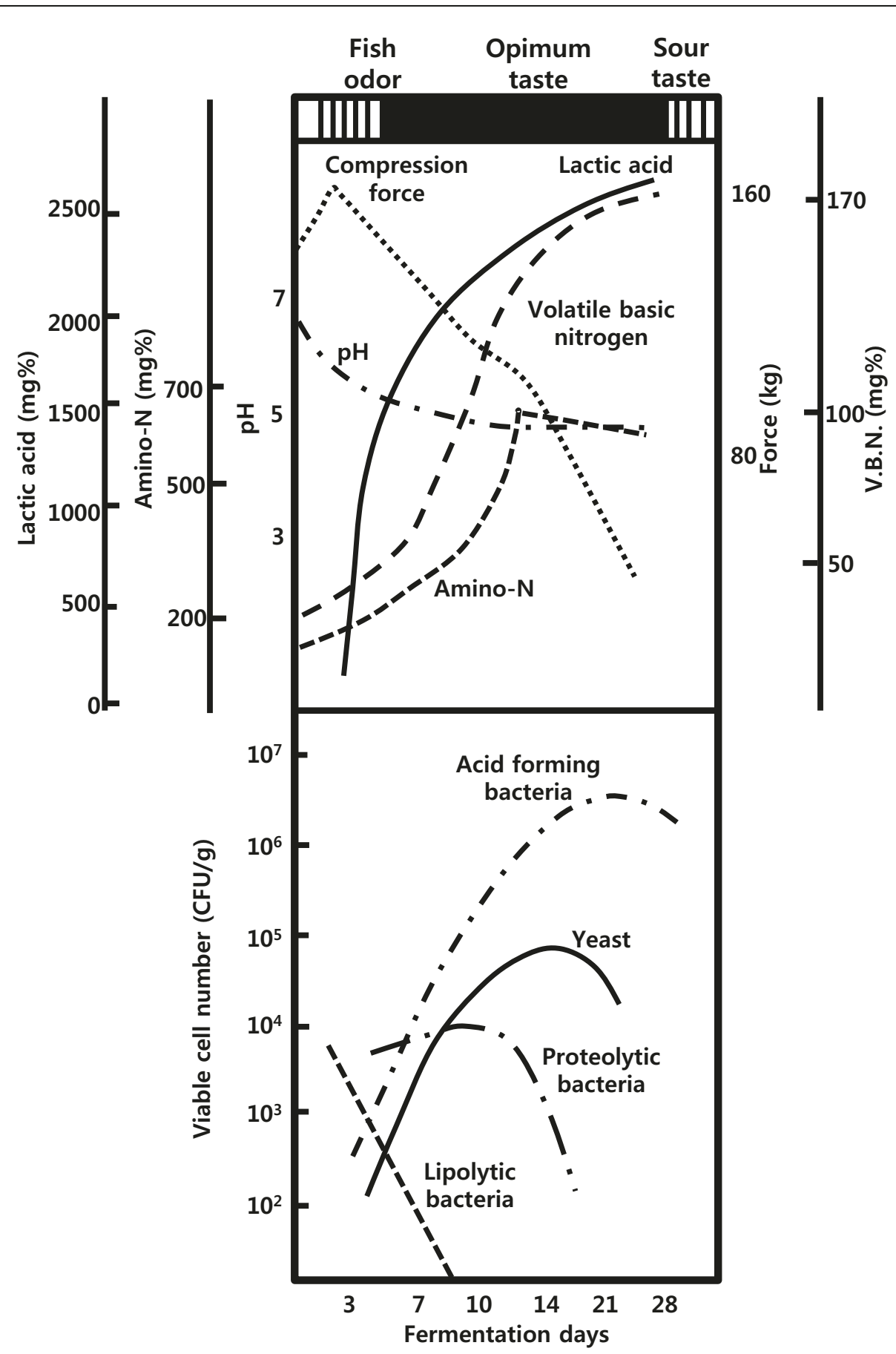

Figure 6 The microbial and biochemical changes during sikhae fermentation. Adapted from Lee, 1994 [1].

shows the biochemical changes in kimchi during fermentation [7]. Optimum taste is attained when the $\mathrm{pH}$ and acidity reach approximately 4.0-4.5 and 0.5-0.6 (lactic acid equivalent \%), respectively. Vitamin $C$ content is maximal at this point [15]. At a higher fermentation temperature, the ripening time is decreased; kimchi ripens in
1 week at 15 and in 3 days at 25 [7]. Before-ripening, $L$. mesenteroides is the dominant microorganism, whereas Lactobacillus species are the major organisms in overripened kimchi (Figure 9) [1].

The dominant species of Lactobacillus in the later stages of kimchi fermentation vary according to the 


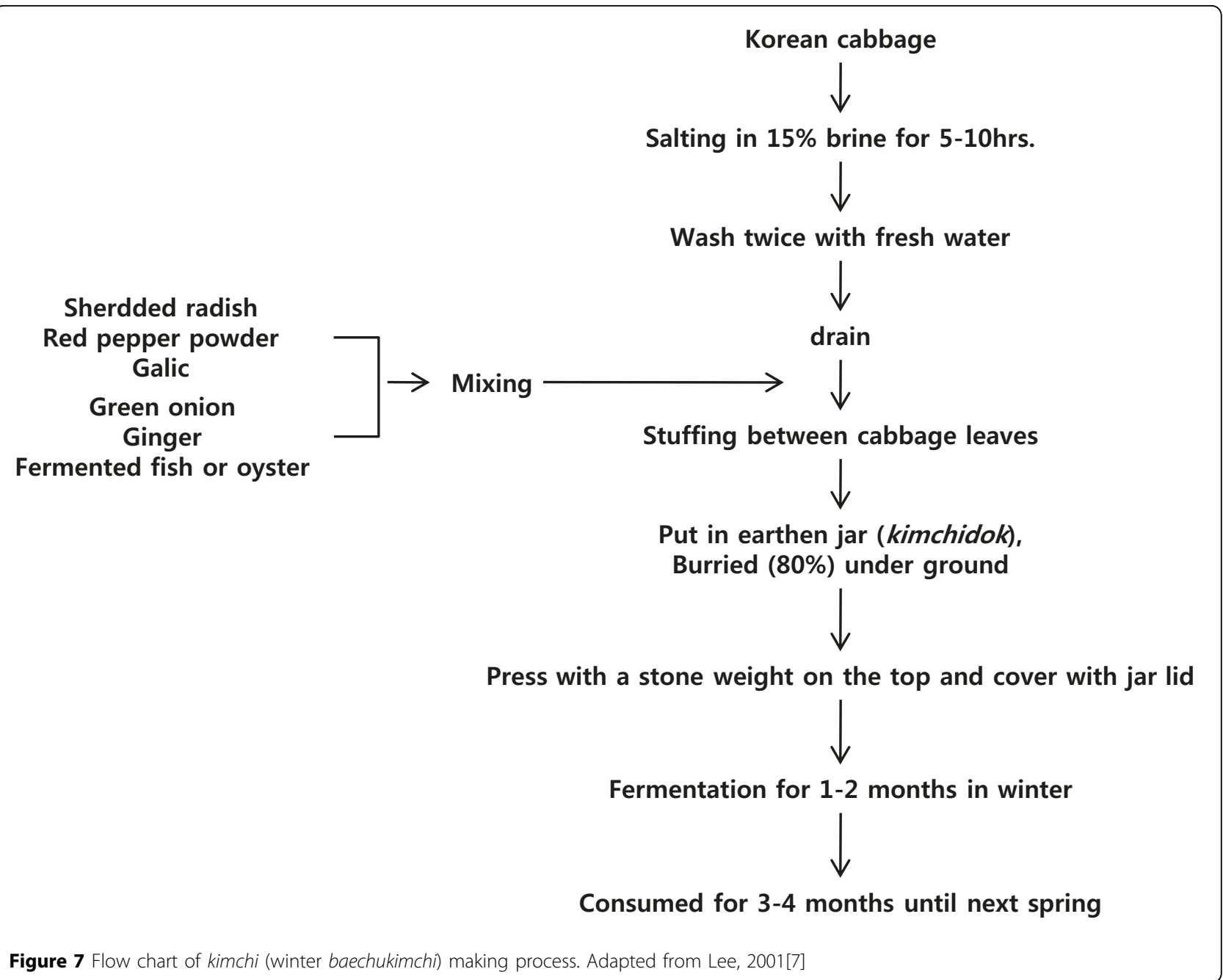

fermentation temperature; Lb. plantarum and Lactobacillus brevis dominate fermentations carried out at 20-30 while Lactobacillus maltaromicus and Lactobacillus bavaricus dominate at 5-7. Lb. plantarum is homofermentative and is the highest acid-producing species of this group, yielding three or four times higher DL-lactic acid content than Leuconostoc species [1]. Low temperature is preferred for kimchi fermentation to prevent the production of high amounts of lactic acid and over-ripening as well as to extend the period of optimum taste.

Recently, the genome probing DNA chip (GPM) method was applied to identify and monitor microbial behavior during fermentation. Over 100 species of microorganisms were identified in kimchi fermentation [16]. Among these, Weisella confuse, Leuconostoc citreum, Lactobacillus curvatus, Lactobacillus sakai, and Lb. fermentum were identified as the important microorganisms.

In an inoculation test, the strong anti-pathogenic activity of kimchi was demonstrated (Table 3) [7]. Clostridium perfringens disappeared after 2 days of kimchi fermentation,
Staphylococcus aureus and Salmonella typhymurium after 4 days, and Listeria monocytogenes, Vibrio parahaemolyticus, and Escherichia coli after 5 days; however, the number of lactic acid bacteria increased from $10^{5}$ to $10^{8}[17,7]$. The inhibitory effects of kimchi ingredients, for example garlic, and the fermentation metabolites (organic acids) are well known. Garlic has anti-microbial activity specific to some pathogens while simultaneously having no effect on lactic acid bacteria [14].

Several strains of microorganisms that produce bacteriocin have been isolated from kimchi. Enterococcus faecium in kimchi has a broad spectrum of bacteriocin activities, and several Lactobacillus species have been shown to produce anti-microbial compounds [17,7]. As an example, a heat- and $\mathrm{pH}$-stable bacteriocin, kimchicin GJ7, produced by $L$. citreum GJ7 was isolated. Notably, the presence of a bacteriocin-sensitive strain, Lb. plantarum, was shown to act as an environmental stimulus to activate the production of kimchicin GJ7 by L. citreum [18]. Furthermore, improved quality and shelf-life of kimchi by fermentation 


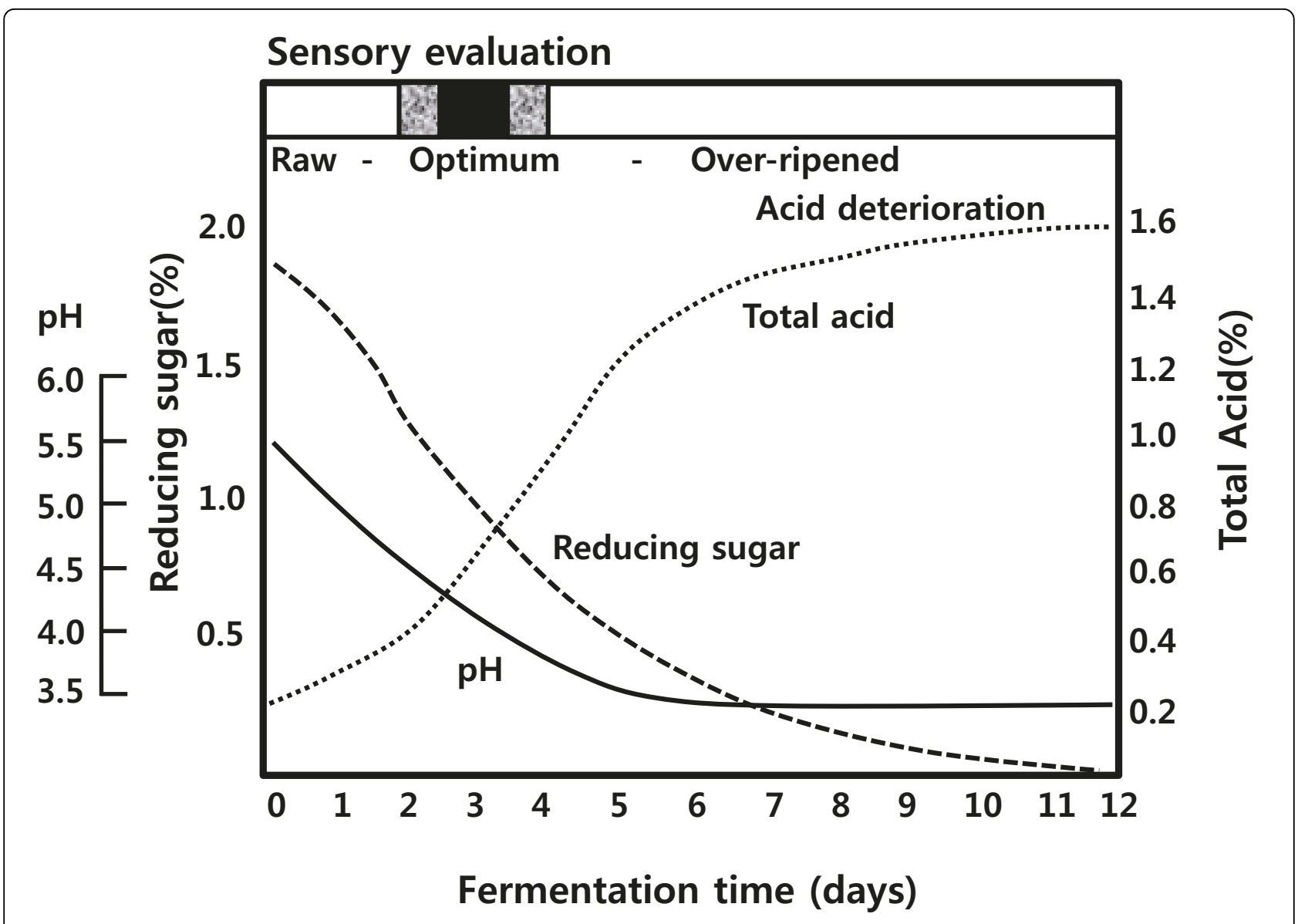

Figure 8 Changes in pH, acidity and reducing sugar content during kimchi fermentation. Adapted from Lee, 2001 [7].

using an induced bacteriocin-producing strain as a starter were previously observed [18]. Recently, a new antifungal compound, 3,6-bis(2-methylpropyl)-2,5-piperazinedion (molecular mass of $226 \mathrm{kDa}$ ), was identified as being produced by a Lb. plantarum strain obtained from kimchi [19], illustrating that the anti-microbial pallet produced during kimchi fermentation may exceed the anti-bacterial activities. Overall, the combination of organic acids and anti-microbial compounds produced during fermentation and the anti-microbial activity of the ingredients regulate the microbiota found in kimchi, and it controls the growth of pathogenic microorganisms without costly treatments and packaging.

The physiological effects of kimchi ingredients and their metabolites have been studied extensively [20,7]. The anti-tumor activities of cabbage and garlic have been reported by many investigators [21], whereas extracts of red pepper powder have been shown to exert inhibitory effects against aflatoxin $\mathrm{B}_{1}$-mediated mutagenesis. Additionally, kimchi contains sufficient concentrations of fiber to prevent constipation and colon cancer, as well as exerting prebiotic effects. Finally, the probiotic effect of lactic acid bacteria in kimchi (grown to $10^{8} / \mathrm{mL}$ ) may assist in digestive and intestinal functions [22] (Table 4) [7].

Thus, kimchi is a synbiotic food consumed widely in Korea [23]. In addition to these physiological effects, the salty taste, fresh carbonated sensation, and crispy texture of kimchi has made it the most favored and indispensable food for Koreans. According to a recent national food consumption survey, a single male Korean adult consumes 50-100 g/day of kimchi in the summer and $100-200 \mathrm{~g} /$ day in winter.

Adaptation of lactic acid bacteria in human food cycle The bacteria isolated from kimchi are identified in Bergey's Manual, but their physiological characteristics seldom match exactly with those characterized in the Manual. L. mesenteroides and Lb. barvaricus isolated from kimchi show many discrepancies in sugar fermentation and vitamin requirements. All Leuconostoc species isolated from kimchi can grow at $\mathrm{pH}$ levels below 4.8 as well as in media containing $7 \%$ ethanol or $6.5 \% \mathrm{NaCl}$ [7]. An interesting observation is that L. mesenteroides subspecies show 


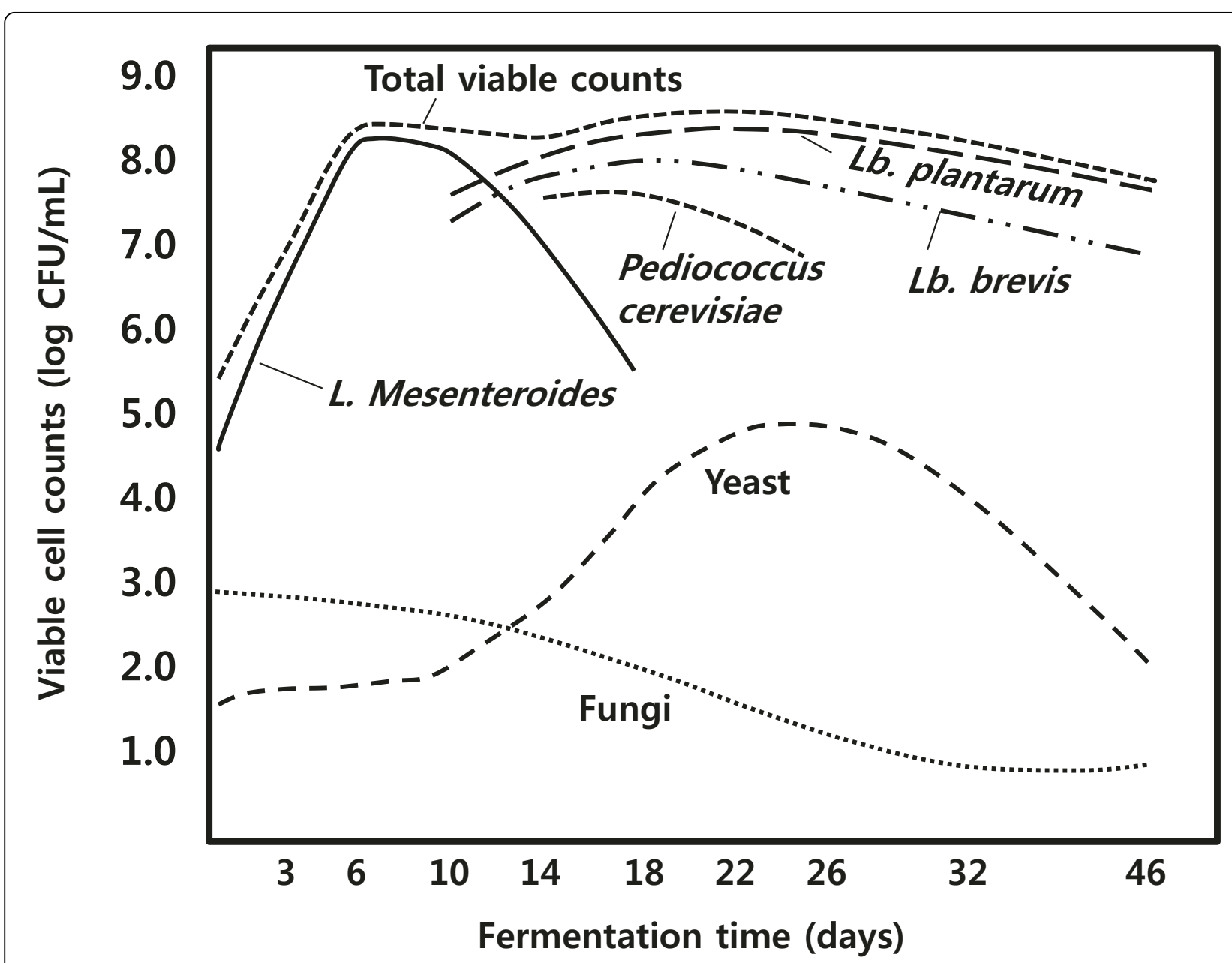

Figure 9 Cahnges in microflora during kimchi fermemtation at $14^{\circ} \mathrm{C}(3.5 \% \mathrm{NaCl})$. Adapted from Lee, 1994 [1].

tolerance in artificial digestive fluid at $\mathrm{pH} 3.0$ and also grow in media containing $10 \%$ or $40 \%$ bile [24]. These properties are similar to those of intestinal microorganisms, such as Lactobacillus acidophilus and Lb. casei, as well as faecal microbial strains. These observations suggest that the major microorganisms in kimchi have adapted to the special environment of Korea as a part of the food cycle from the soil to vegetables, to kimchi, and then to the human intestine, faeces, and the soil again. Adaptations of microorganisms to special environmental conditions have been reported in other fermented foods, i.e. $L$. mesenteroides in cane juice, Leuconostoc. oenos in grape juice, Pediococcus. halophilus in soy sauce, and the abovementioned L. mesenteroides in sikhae [7].

Table 3 Changes in concentrations of intestinal pathogens in kimchi during fermentation at $20^{\circ} \mathrm{C}((\mathrm{CFU} / \mathrm{mL}))$

\begin{tabular}{|c|c|c|c|c|c|c|c|c|}
\hline Fermentation(days) & 0 & 1 & 2 & 3 & 4 & 5 & 6 & 7 \\
\hline $\mathrm{pH}$ & 5.44 & 5.12 & 4.11 & 3.86 & 3.76 & 3.70 & 3.66 & 3.63 \\
\hline Cl. perfringens & $4.3 \times 10^{4}$ & $2.7 \times 10^{2}$ & - & - & - & - & - & - \\
\hline Staph. aureus & $2.9 \times 10^{4}$ & $4.5 \times 10^{4}$ & $2.8 \times 10^{3}$ & $5.0 \times 10$ & - & - & - & - \\
\hline S. typhimurium & $3.6 \times 10^{4}$ & $2.2 \times 10^{4}$ & $5.8 \times 10^{3}$ & $1.1 \times 10^{2}$ & - & - & - & - \\
\hline L. monocytogenes & $6.3 \times 10^{4}$ & $3.7 \times 10^{4}$ & $4.5 \times 10^{3}$ & $2.6 \times 10^{2}$ & $4.0 \times 10$ & - & - & - \\
\hline V. parahaemolyticus & $2.3 \times 10^{4}$ & $2.1 \times 10^{4}$ & $7.3 \times 10^{3}$ & $5.5 \times 10^{2}$ & $9.0 \times 10$ & - & - & - \\
\hline E. coli & $5.2 \times 10^{4}$ & $3.3 \times 10^{4}$ & $2.9 \times 10^{3}$ & $3.3 \times 10^{2}$ & $3.0 \times 10$ & - & - & - \\
\hline Lactic acid bacteria & $2.0 \times 10^{5}$ & $7.3 \times 10^{6}$ & $2.8 \times 10^{8}$ & $5.7 \times 10^{8}$ & $6.1 \times 10^{8}$ & $5.6 \times 10^{8}$ & $5.8 \times 10^{8}$ & $6.0 \times 10^{8}$ \\
\hline Total bacteria & $4.4 \times 10^{4}$ & $3.6 \times 10^{7}$ & $9.3 \times 10^{8}$ & $1.2 \times 10^{9}$ & $1.5 \times 10^{9}$ & $1.4 \times 10^{9}$ & $1.6 \times 10^{9}$ & $1.4 \times 10^{9}$ \\
\hline
\end{tabular}

Adapted from Lee, 2001 [7]. 
Table 4 Biologically active compounds in kimchi

\begin{tabular}{|c|c|c|}
\hline Chemical compounds & Occurrence & Possible effect \\
\hline Benzylisothiocyanate & $\begin{array}{l}\text { Chinese } \\
\text { cabbage }\end{array}$ & antibiotic \\
\hline Indol compound & $\begin{array}{l}\text { allium } \\
\text { vegetable }\end{array}$ & anticarcinogenic \\
\hline $\begin{array}{l}\text { Thiocyanate, } \\
\text { Flavonoid }\end{array}$ & Red pepper & immune stimulant \\
\hline sistosterol & $\begin{array}{l}\text { Chinese } \\
\text { cabbage }\end{array}$ & $\begin{array}{l}\text { reducing the cholesterol } \\
\text { level }\end{array}$ \\
\hline Diallysulfide & $\begin{array}{l}\text { allium } \\
\text { vegetable }\end{array}$ & anticarcinogenic \\
\hline Diallytrisulfide & & antioxidant \\
\hline Diallymethylsulfide & & fibrinolytic \\
\hline Gingerrol & ginger & antibiotic \\
\hline Gingerin & & fibrinolytic \\
\hline \multirow[t]{2}{*}{ Capsaicin } & red pepper & laxative \\
\hline & & $\begin{array}{l}\text { secretion of } \\
\text { neuropeptides }\end{array}$ \\
\hline Lactic acid bacteria & Kimchi & antagonistic \\
\hline Bacteriocine & Kimchi & antibiotic \\
\hline L-(+) lactic acid & Kimchi & $\begin{array}{l}\text { modulation of T-cell } \\
\text { function }\end{array}$ \\
\hline Acethylcholine & Kimchi & laxation \\
\hline Dextran & Kimchi & laxation \\
\hline$\gamma$-aminobutyric acid & Kimchi & laxation \\
\hline Acetate & Kimchi & antibiotic \\
\hline
\end{tabular}

Adapted from Lee, 2001 [7].

\section{Conclusions}

Lactic acid bacteria play important roles in many Asian fermented foods, especially in non-dairy fermented vegetable products. The probiotic functions of lactic acid bacteria in non-dairy fermented foods in Asia have not been fully investigated. L. mesenteroides present in kimchi, for example, probably have probiotic effects. In fact, Koreans who travel overseas for several days without kimchi often experience uncomfortable stomach symptoms and poor digestion. More research is needed to identify the lactic acid bacteria in Asian fermented foods and their physiological functions in the human diet.

\section{Acknowledgements}

The authors deeply appreciate the valuable comments and editorial assistance of Prof. Michiel Kleerebezem, NIZO food research and Wageningen University, The Netherlands.

This article has been published as part of Microbial Cell Factories Volume 10 Supplement 1, 2011: Proceedings of the 10th Symposium on Lactic Acid Bacterium. The full contents of the supplement are available online at http:// www.microbialcellfactories.com/supplements/10/S1.

\section{Authors' contributions}

Sook Jong Rhee - assisted in collection of data and editing of the review paper.

Jang-Eun Lee - assisted in collection of data and editing of the paper.

Cherl-Ho Lee - principal researcher and corresponding author.
Published: 30 August 2011

\section{References}

1. Lee $\mathrm{CH}$ : Importance of lactic acid bacteria in non-dairy food fermentation, in Lactic Acid Fermentation of Non-dairy Food and Beverages. HarnLimWon;Lee, C.H., Adler-Nissen, J. and Barwald, G 1994.

2. Rhee SJ, Lee CYJ, Kim KK, Lee CH: Comparison of the traditional (samhaeju) and industrial (Congju) rice wine brewing in Korea. Korean J. Food Sci. Technol 2003, 12:242-247.

3. Lee $\mathrm{CH}$, Cho TS, Lim MH, Kang Jh, Yang HC: Studies on the Sik-hae fermentation made by flat-fish. Korean J. Appl. Microbiol. Bioeng 1983, 11:53-58.

4. Orillo CA, Pederson CS: Lactic acid bacterial fermentation of Burong dalag. Appl. Microbiol 1968, 16:1669-1671.

5. Lee CH: Food biotechnology. In Food Science and Technology CampbellPlatt, G., Wiley-Blackwell 2009, 85-113.

6. Steinkraus KH: Handbook of Indigenous Fermented Foods. Marcel Dekker, New York; 1988.

7. Lee $\mathrm{CH}$ : Fermentation Technology in Korea. Korea University Press; 2001.

8. Lee CH, Adler-Nissen J, Barwald G: Lactic Acid Fermentation of Non-dairy Food and Beverages HarnLimWon; 1994.

9. Mukherjee SK, Albury MN, Pederson CS, Van Veen AG, Steinkraus KH: Role of Leuconostoc mesenteroides in leavening the batter of idle, a fermented food of India. Appl. Microbiol 1965, 13:227-231.

10. Batra LR, Millner PD: Some Asian fermented foods and beverages and associated fungi. Mycologia 1974, 66:942-950.

11. Rosanaphaiboon T: Khanom-jeen: Traditional food and processing in Asia. Ando. NODAI Research Institute, Tokyo;F. Yanagida, Y. Takai, S. Homa, S. Kato and Y 1987:48.

12. Jamias-Apilado RB, Mabesa RC: Influence of rice and salt on the rate of rice-fish fermentation. The Philippine J. of Biotechnol 1991, 1:160.

13. Lee $\mathrm{CH}$ : Fish fermentation technology. Korean J. Appl. Microbiol. Bioeng 1989, 17:645-654.

14. Souane M, Kim YB, Lee CH: Microbial characterization of Gajami-sikhae fermentation. Korean J. Appl. Microbial. Bioeng 1987, 15:150-157.

15. Lee $\mathrm{CH}$ : Lactic acid fermented foods and their benefits in Asia. Food Control 1997, 9:259-269.

16. Park HY, Bae JW, Lee IS, Kim HI, Lee JS, Ryu BH, Chang YH, Yoon JH, Nam YD, Kang KH: Kimchi starter culture and molecular monitoring technology for the production of new functional Kimchi. Korean Kimchi and Fermentation Technology, Proceedings of Korean Society of Microbiology and Biotechnology Symposium Seoul; 2005, 49-53.

17. Ha DM: Suppression of acidic deterioration of Kimchi during the fermentation process. The Science of Kimchi, Proceedings of the Korean Society of Food Science and Technology Symposium Seoul; 1994, 43-61.

18. Chang JY, Chang HC: Improvements in the quality and shelf life of Kimchi by fermentation with the induced bacteriocin-producing strain, Leuconostoc citreum GJ7 as a starter. J. Food Sci 2010, 75:103-110.

19. Yang EJ, Chang HC: Purification of a new antifungal compound produced by AF1 isolated from Kimchi. International J. Food Microbiol 2010, 139:56-63.

20. Park KY, Choi HS: The anti-mutagenic and anti-carcinogenic activity of Kimchi. The Science of Kimchi, Proceedings of the Korean Society of Food Science and Technology Symposium Seoul; 1994, 205-225.

21. Park KY, Kim SH, Suh MJ, Chung HY: Inhibitory effect of garlic on the mutagenicity in Salmonella assay system and on the growth of HT-29 human colon carcinoma cells. Korean J. Food Sci. Technol 1991, 23:370-374

22. Oh YJ, Hwang IJ, Leitzmann C: Nutritional and physiological evaluation of Kimchi. The Science of Kimchi, Proceedings of the Korean Society of Food Science and Technology Seoul; 1994, 226-246.

23. Lee $\mathrm{CH}$ : Kimchi, synbiotic food of Korean. Proceedings of Kimchi Symposium IFT Annual Meeting; 2007, 1-18.

24. So MH: Characterization of psychotrophic lactic acid bacteria isolated from Korean Kimchi. Ph.D. Thesis, Department of Food Technology, Korea University, Seoul, Korea; 2001.

doi:10.1186/1475-2859-10-S1-S5

Cite this article as: Rhee et al:: Importance of lactic acid bacteria in Asian fermented foods. Microbial Cell Factories 2011 10(Suppl 1):S5. 